\title{
Betegforgalmi trendek multidiszciplináris sürgősségi osztályon
}

\author{
Varga Csaba dr. ${ }^{1}$ - Lelovics Zsuzsanna dr. ${ }^{2}$ \\ Soós Viktor ${ }^{1}$ - Oláh Tibor dr. ${ }^{1}$ \\ ${ }^{1}$ Somogy Megyei Kaposi Mór Oktató Kórház, Kaposvár \\ ${ }^{2}$ Kaposvári Egyetem, Kaposvár
}

\begin{abstract}
Bevezetés: Magyarországon az elmúlt években húsznál több új sürgősségi osztályt adtak át. A betegforgalmi adatok, betegségek, indikátorok ismeretének hiánya számtalan logisztikai, szervezési problémát vethet fel. Célkitüzés: A sürgősségi betegellátás adatainak elemzése és rendelkezésre bocsátása a hatékony múködtetés elősegítésére. Módszer: A Somogy Megyei Kaposi Mór Oktató Kórház multidiszciplináris Sürgősségi Betegellátó Centrumának hároméves betegforgalmi $(\mathrm{n}=106$ 203), epidemiológiai, triázs és a betegségek nemzetközi klasszifikációjának adatait elemeztük.

Eredmények: A betegek 73\%-a 24 órán belül otthonába bocsátható volt. Hospitalizációt (21\%) döntően belgyógyászati, gyermekgyógyászati, valamint idegrendszeri betegségek indikáltak. A kritikus állapotú betegek aránya kicsi $(<2 \%)$. Jellegzetes napszaki, heti és szezonális ingadozások figyelhetők meg. A betegforgalom domináns részét a sérülések, mérgezések adták (40\%). Az állapotstabilizálás eredményességét igazolja a kis $(0,3 \%)$ halálozási ráta.

Következtetések: A szerzők eredményei megerősítik, hogy a vizsgált sürgősségi ellátás betegbiztonsági értéke nagy és mentesítheti a kórházi osztályokat az indokolatlan betegfelvétel alól. Orv Hetil. 2017; 158(21): 811-822.
\end{abstract}

Kulcsszavak: sürgősségi ellátás, triage (triázs), BNO, epidemiológia, szezonalitás

\section{Patient turnover in a multidisciplinary emergency department}

Introduction: More than twenty emergency departments were opened across Hungary in the past years. Data deficiency on patient flow, trends and lack of knowledge of indicators could raise numerous logistical and organisational problems.

Aim: Collection, analysis and provision of data to facilitate successful operations of emergency medical care services. Method: During a three-year period investigated, at the multidisciplinary Emergency Department of "Moritz Kaposi" Teaching Hospital, data on patient flow $(\mathrm{n}=106,203)$, epidemiology, triage and international classification of diseases were analysed.

Results: Analysis showed $73 \%$ of patients were suitable for medical discharge within 24 hours. Predominantly internal medicine, paediatric and neurological diseases indicated hospitalisation (21\%). Patients in critical condition were found to be low $(<2 \%)$. Distinct diurnal, weekly, monthly variations were found. Majority of cases were injuries and intoxications $(40 \%)$. Low mortality rate $(0.3 \%)$ validates the effectiveness of stabilisation.

Conclusions: The patient safety value of the examined emergency medical care is great, and could exempt the hospital wards from unjustified hospitalisations of the patients.

Keywords: emergency service, triage, ICD-10, epidemiology, seasonality

Varga Cs, Lelovics Zs, Soós V, Oláh T. [Patient turnover in a multidisciplinary emergency department]. Orv Hetil. 2017; 158(21): 811-822.

(Beérkezett: 2017. március 4.; elfogadva: 2017. április 10.)

\section{Rövidítések}

BNO = Betegségek Nemzetközi Osztályozása; CTAS = Canadian Triage and Acuity Scale (kanadai triázsskála); KMOKSBC = Somogy Megyei Kaposi Mór Oktató Kórház, Sürgősségi Betegellátó Centrum
Hazánkban az elmúlt években - az európai uniós támogatásoknak köszönhetően - több tucat, az akut ellátás frontvonalát jelentő sürgősségi osztály kezdte meg múködését. Az osztályok szervezése kellő szakmai és logisztikai ismeretet igényel, annak ellenére, hogy a mü- 
1. táblázat |A triázsszintek felosztása a hozzárendelt ellátási időkorlátokkal

\begin{tabular}{lccc}
\hline Sürgősség szintje & Triázsszint & Orvos & Nővér \\
\hline Azonnali (resuscitatio) & I. & Azonnal & Azonnal \\
Kritikus & II. & $<15$ perc & Azonnal \\
Sürgős & III. & $<30$ perc & $<30$ perc \\
Kevésbé sürgős & IV. & $<60$ perc & $<60$ perc \\
Halasztható & V. & $<120$ perc & $<120$ perc \\
\hline
\end{tabular}

2. táblázat | A Somogy Megyei Kaposi Mór Oktató Kórház Sürgősségi Betegellátó Centrumában megjelent betegek összefoglaló adatai

\begin{tabular}{|c|c|c|c|c|}
\hline & 2013. év & 2014. év & 2015. év & $\begin{array}{l}\text { 2013- } \\
\text { 2015. év }\end{array}$ \\
\hline \multicolumn{5}{|l|}{ Betegek száma és aránya } \\
\hline $\begin{array}{l}\text { Férfiak [n] } \\
(\%)\end{array}$ & $\begin{array}{r}17928 \\
(50,5)\end{array}$ & $\begin{array}{r}18393 \\
(50,5)\end{array}$ & $\begin{array}{r}17454 \\
(50,9)\end{array}$ & $\begin{array}{r}53775 \\
(50,6)\end{array}$ \\
\hline $\begin{array}{l}\text { Nők [n] } \\
(\%)\end{array}$ & $\begin{array}{r}17565 \\
(49,5)\end{array}$ & $\begin{array}{r}18010 \\
(49,5)\end{array}$ & $\begin{array}{r}16853 \\
(49,1)\end{array}$ & $\begin{array}{r}52428 \\
(49,4)\end{array}$ \\
\hline Összesen & 35493 & 36403 & 34307 & 106203 \\
\hline \multicolumn{5}{|l|}{ Életkor és korcsoportok } \\
\hline Átlagéletkor [év] $( \pm S D)$ & $\begin{array}{r}44,5 \\
( \pm 25,6)\end{array}$ & $\begin{array}{r}44,9 \\
( \pm 25,7)\end{array}$ & $\begin{array}{r}45,1 \\
( \pm 25,9)\end{array}$ & $\begin{array}{r}44,8 \\
( \pm 25,7)\end{array}$ \\
\hline Medián & 45,2 & 45,8 & 46,1 & 45,7 \\
\hline 18 év alattiak [\%] & 21,2 & 20,9 & 20,8 & 20,0 \\
\hline 18-65 év közöttiek [\%] & 53,8 & 53,7 & 53,0 & 53,5 \\
\hline 65 év felettiek [\%] & 25,0 & 25,4 & 26,2 & 25,5 \\
\hline \multicolumn{5}{|l|}{ Érkezés módja } \\
\hline Saját lábán [\%] & 63,0 & 63,5 & 64,0 & 63,4 \\
\hline Egyedül [\%] & 16,3 & 16,5 & 18,3 & 16,7 \\
\hline Kísérővel [\%] & 46,7 & 47,1 & 45,6 & 46,7 \\
\hline $\begin{array}{l}\text { Országos Mentőszolgálat } \\
\text { szállította [\%] }\end{array}$ & 36,8 & 36,3 & 35,7 & 36,4 \\
\hline $\begin{array}{l}\text { Reanimációs team } \\
\text { riasztása [\%] }\end{array}$ & 0,2 & 0,2 & 0,3 & 0,2 \\
\hline
\end{tabular}

\begin{tabular}{|c|c|c|c|c|}
\hline \multicolumn{5}{|l|}{ Triázsszint } \\
\hline Triázs I. [n] & 229 & 218 & 231 & $\begin{array}{r}678 \\
(0,6 \%)\end{array}$ \\
\hline Triázs II. [n] & 542 & 438 & 426 & $\begin{array}{r}1406 \\
(1,3 \%)\end{array}$ \\
\hline Triázs III. [n] & 7336 & 8132 & 8014 & $\begin{array}{c}23482 \\
(22,1 \%)\end{array}$ \\
\hline Triázs IV. [n] & 13103 & 14607 & 13783 & $\begin{array}{r}41493 \\
(39,1 \%)\end{array}$ \\
\hline Triázs V. [n] & 14283 & 13008 & 11853 & $\begin{array}{r}39144 \\
(36,9 \%)\end{array}$ \\
\hline \multicolumn{5}{|l|}{ A betegek ellátás utáni sorsa } \\
\hline Hospitalizált betegek [\%] & 22,2 & 21,0 & 20,9 & 21,4 \\
\hline Önkényesen távozók [\%] & 3,1 & 3,0 & 2,7 & 3,0 \\
\hline $\begin{array}{l}\text { Önkényesen távozók } 48 \\
\text { órán belüli } \\
\text { readmissziója [\%] }\end{array}$ & 7,8 & 4,4 & 3,7 & 5,4 \\
\hline
\end{tabular}

2013. év 2014. év 2015. év 2013-

2015. év

\begin{tabular}{lcccc}
\hline $\begin{array}{l}\text { Triázs után } \\
\text { továbbirányított [\%] }\end{array}$ & 1,5 & 1,1 & 1,5 & 1,4 \\
$\begin{array}{l}\text { Más fekvốbeteg- } \\
\text { Máng }\end{array}$ & 0,3 & 0,4 & 0,4 & 0,4
\end{tabular}

intézménybe áthelyezett

[\%]

\begin{tabular}{lrrrr} 
Meghalt [\%] & 0,3 & 0,3 & 0,4 & 0,3 \\
\hline Ellátás után otthonába & 71,9 & 73,4 & 73,5 & 72,9
\end{tabular}

bocsátott [\%]

Hazabocsátott betegek tartózkodási idő szerinti megoszlása $(\mathrm{n}=77945)$

\begin{tabular}{lrrrr}
$\begin{array}{l}<6 \text { óra }[\mathrm{n}] \\
(\%)\end{array}$ & $\begin{array}{rrr}18504 \\
(72,1)\end{array}$ & $\begin{array}{r}18547 \\
(68,9)\end{array}$ & $\begin{array}{r}17754 \\
(69,9)\end{array}$ & $\begin{array}{r}54775 \\
(70,3)\end{array}$ \\
$\begin{array}{l}\text { 6-24 óra [n] } \\
(\%)\end{array}$ & 7020 & 8185 & 7481 & 22686 \\
$>24$ óra [n] & $(27,3)$ & $(30,4)$ & $(29,5)$ & $(29,1)$ \\
$(\%)$ & 162 & 176 & 146 & 484 \\
$(0,6)$ & $(0,7)$ & $(0,6)$ & $(0,6)$ \\
\hline
\end{tabular}

24 órán belül

hazabocsátottak

48 órán belüli

readmissziója [\%]

$\begin{array}{lllll}\text { Reanimációs team } & 80 & 70 & 89 & 239\end{array}$

riasztása

(egyéb kórházi osztályos

betegek) $[\mathrm{n}]$

Sikeres $[\mathrm{n}]$

Sikertelen reanimáció

$\begin{array}{rr}34 & 105 \\ & (43,9 \%)\end{array}$

(meghalt) [n]

$56,1 \%)$

$\begin{array}{lllll}\text { KMOK-SBC-ban } & 108 & 125 & 118 & 351\end{array}$

elhunytak [n]

$\begin{array}{llllll}\text { Összes elhunyt [n] } & 156 & 161 & 168 & 485\end{array}$

ködtetés alapjául szolgáló jogszabályi előírások, minimumrendelet $[1,2]$ rendelkezésre állnak. Egy évtizede az 52/2006. EüM rendelet a sürgős szükség körébe tartozó betegségcsoportokat és kórképeket is definiálja [3]. A humánerőforrás-gazdálkodáshoz, a szakmai anyagok és a diagnosztikai háttér tervezéséhez, a felelősségteljes döntéshozatalhoz éppúgy, mint a háttérszakmák igénybevételének felméréséhez segítséget jelenthetnek a naprakész, részletes és objektív epidemiológiai és betegforgalmi adatok [4]. A releváns közlemények többnyire angolszász országokból [5-8] és a skandináv térségből $[9,10]$ származnak. Adataik az eltérő demográfiai és fejlettségi körülmények, az egészségügyi struktúra és kultúra különbözősége miatt nehezen adaptálhatók a hazai viszonyokra. A népesség elöregedésével jelentkező és a szociális ellátórendszer hiányosságaiból adódó problémák egy része - ahogy azt nemzetközi tanulmányok is igazolják $[11,12]$ - a sürgősségi ellátórendszerben csapódik le.

Ismereteink szerint hazánkban nem állnak rendelkezésre egzakt, hivatkozható, naprakész epidemiológiai, betegforgalmi és a betegségekre vonatkozó adatok. 
Nagyszámú, különböző tünetekkel és panaszokkal érkező beteg ellátása, a prioritás meghatározása csak osztályozást, a triázsvizsgálatot követően lehetséges. A triázs olyan értékelőrendszer, amelynek segítségével nagy valószínűséggel meghatározható az ellátás szükséges szintje és időbeli sürgőssége (1. táblázat). Minden esetben folyamatot jelent, nem pedig számot egy skálán [13].

Célul túztük ki egy nagy forgalmú multidiszciplináris sürgősségi centrumban megjelenő betegek adatainak epidemiológiai elemzését azzal a szándékkal, hogy a kórházak érintett szakmai vezetői segítséget kapjanak a szükséges háttérosztályok szervezéséhez és az intézményi kubatúra tervezéséhez [2]. Elemeztük a betegcsoportok összetételét és jellegét a betegségek nemzetközi osztályozására szolgáló kódrendszer alapján [14]. Célunk volt az érkezés körülményeinek, a betegforgalom napszaki, időszaki, évszaki, valamint a betegosztályozás szerinti - retrospektív - elemzése. Fontosnak véltük annak feltárását is, hogy milyen arányban kerültek a betegek időlimiten belül ellátásra.

\section{Betegek és módszer}

A Somogy Megyei Kaposi Mór Oktató Kórház Sürgősségi Betegellátó Centrumában (KMOK-SBC; III. progresszivitási szintű ellátóhely) 2013. január l. és 2015. december 31. között - egykapus beléptetési rendszerben - megjelent betegek ( $n=106203$ ) adatait elemeztük. Vizsgálatunk kezdetekor a kórállapot súlyosságát és a beavatkozás sürgősségét jelző ötfokozatú osztályozórendszert alkalmaztunk, amelynek alapját a kanadai triázsskála képezte (Canadian Triage and Acuity Scale) [15] a különböző szintekhez rendelt időkorlátok figyelembevételével (1. táblázat). A skála hazai adaptációja elemzési periódusunk alatt, 2013 őszén történt Magyar Sürgősségi Triázs Rendszer [13] néven. Ez eredményeinket nem befolyásolta, mivel a kikérdezés módja és az osztályozás szempontjai nem változtak. Betegeinkról minden esetben észlelési dokumentáció készült, amely tartalmazta a releváns időpontokat, a triázsbesorolást és az ellátást segítő pontrendszereket (Glasgow Coma Scale - GCS [16], Injury Severity Score - ISS [17], Revised Trauma Score - RTS [18], NIH Stroke Scale - NIHSS [19]).

A dokumentum az akut ellátás számos területén elterjedt ABCD (airway, breathing, circulation, disability) megközelítést használja [20]. A bemutatott adatok rögzítése prospektív, míg az adatgyújtés és epidemiológiai jellegú adatelemzés retrospektív, a kórlapok feldolgozásával történt. Az adatokat a nemzetközi szakirodalomban használt és a hazai jellemzők ismeretében felállított szempontok alapján elemeztük a leíró statisztika módszereivel, SPSS 23.0 programmal. Az adatok megjelenítése MS-Office Excel 2013 szoftver segítségével történt. Az elemzéshez meghatároztuk az egyes csoportok átlagait, azok szórásait ( \pm SD-érték), valamint minimum- és maximumértékeit. Az adatelemzést a 95\%-os konfidenciaintervallumok összehasonlításával és kétmintás t-próbával végeztük [21]. A BNO-föcsoportok gyakoriságát nemcsak a teljes populációra, hanem az évenként megjelenő betegek, illetve a korcsoportok almintáira is vizsgáltuk.

\section{Eredmények}

\section{A betegek neme és életkora}

Az elemzésünk mindhárom évében nagyobb arányban jelentkeztek férfiak ( $\mathrm{n}=53$ 775), mint nők $(\mathrm{n}=52$ 428) a Sürgősségi Betegellátó Centrumban. Átlagosan minden ötödik beteg (21\%) tizennyolc év alatti, azaz gyermekkorú volt (2. táblázat). A hatvanöt év felettiek aránya $25,5 \%$ volt, ezen belül a nyolcvan év felettiek nagy aránya $(8,2 \%)$ figyelhető meg. Az aktív életkor végéig férfidominancia észlelhető, amely tendencia csak az idősebb életkorban változik (1. ábra).

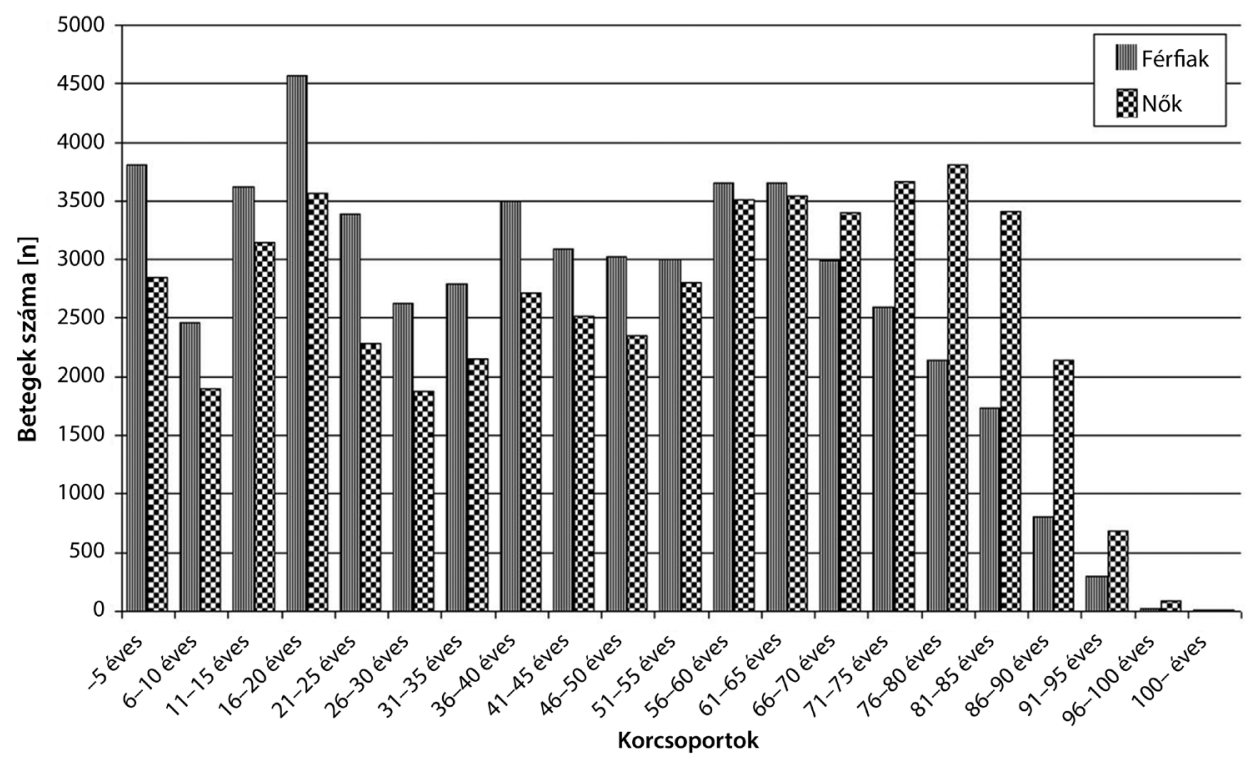

1. ábra | A KMOK-SBC betegeinek száma ötévenkénti korcsoportokban, 2013-2015. év (n = 106 203) 


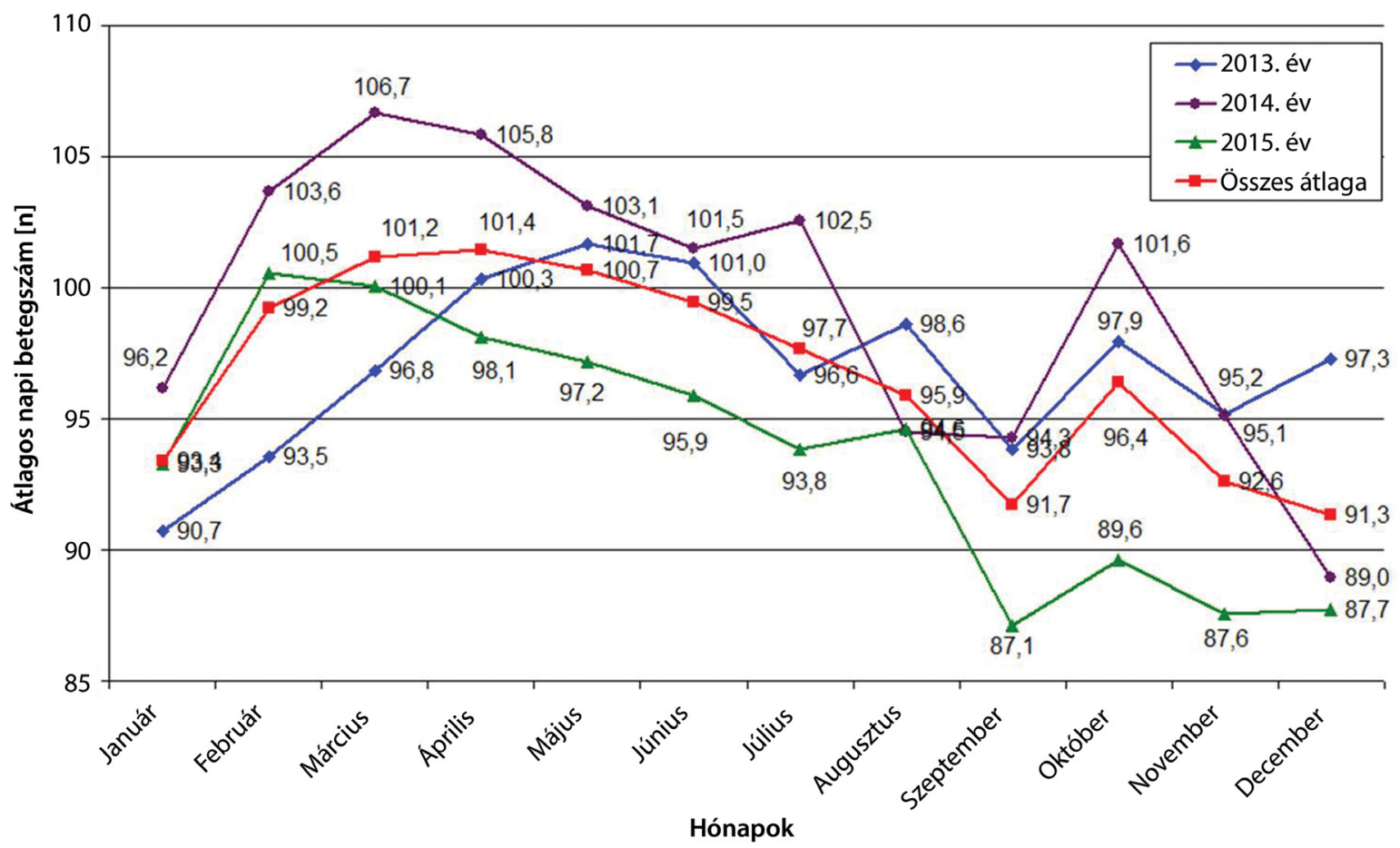

2. ábra $\quad$ A Somogy Megyei Kaposi Mór Oktató Kórház Sürgősségi Betegellátó Centrumának 2013-2015. évi átlagos napi betegforgalma havi bontásban $(\mathrm{n}=106203)$

\section{Érkezés ideje}

A betegforgalom szembetűnő „szezonális” ingadozást mutatott. A vizsgált három év első negyedében (januártól márciusig) szignifikánsan $(\mathrm{p}<0,05)$ több beteg jelentkezett ellátásra, mint a második fél évben, a változás különösen ősszel szembetûnő (2. ábra).

Munkanapokon a munkakezdéssel párhuzamosan kezdődött a betegáramlás, amelynek csúcsa a déli órákra tehető. Az igénybevétel a késő esti órákban csökkent a legalacsonyabb szintre, bár a személyzet leterhelése folyamatos. Hétvégén és munkaszüneti napokon a tendencia hasonló, azonban a hétvégi éjszakai igénybevétel meghaladta a munkanapokon észlelt szintet (3. ábra).

\section{Az érkezés módja}

A vizsgált periódusban az érkezés módja szerinti megoszlásban nem volt változás (2. táblázat). Betegeink közel kétharmada kísérôvel vagy egyedül érkezett, a többieket az Országos Mentőszolgálat egységei szállították. A Heliporton keresztül intézményünk a repülési körülményektől függő́n légi úton is folyamatosan elérhető. Helikopterrel legnagyobb számban a magas időfaktorú traumás sérültek érkeztek (3. táblázat). A 2014. és a 2015. évben már direkt transzportok történtek az intézmény - vizsgált periódus alatt induló - intervenciós egységébe, coronaria- vagy neurointervenció céljából. Az érkezés módja szoros összefüggést mutatott a triázsszinttel. Az I-III. szintre sorolt betegek között a mentő-

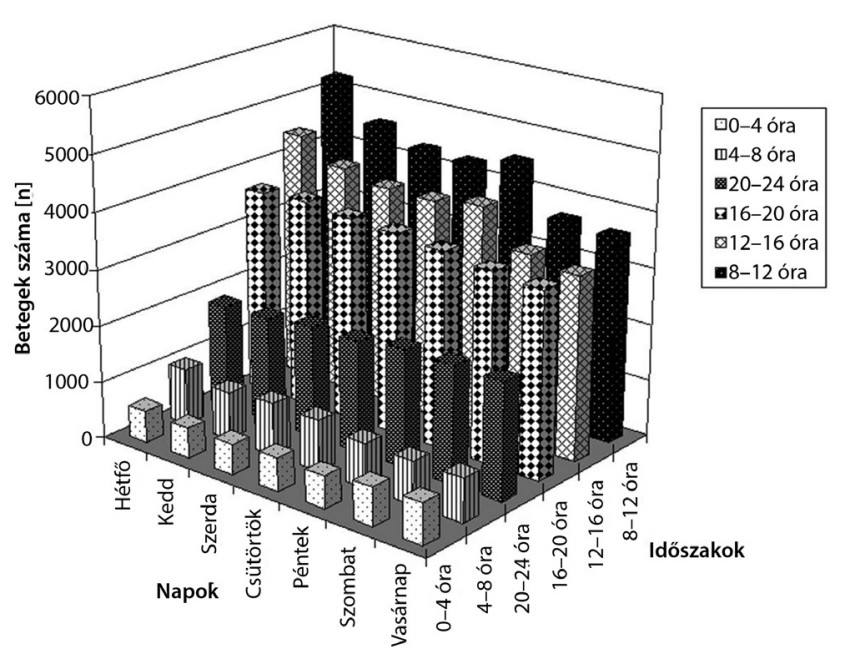

3. ábra $\quad$ A Somogy Megyei Kaposi Mór Oktató Kórház Sürgősségi Betegellátó Centrumában megjelent betegek száma napi és négyórás bontásban, 2013-2015 (n = 106203 )

vel érkezők aránya szignifikánsan $(p<0,05)$ nagyobb volt. A IV. és az V. szinteken dominánssá vált a kísérővel vagy egyedül érkezők aránya (4.ábra).

\section{Betegosztályozás, triázs, idóablakok}

Az ellátás megkezdésének átlagos ideje az I. triázsszinten $3,6 \pm 5,8$; a II. szinten $7,0 \pm 11,8$; a III. szinten $23,2 \pm 26,1 ;$ a IV. szinten $37,8 \pm 38,3$ és az V. triázsszinten $44,2 \pm 43,5$ perc volt. 
A Somogy Megyei Kaposi Mór Oktató Kórház Sürgősségi Betegellátó Centrumába légi úton érkezett betegek száma $\mathrm{BNO}$ fő́csoport szerinti bontásban

\begin{tabular}{|c|c|c|c|c|}
\hline BNO-fócsoportok & 2013. év & 2014. év & $\begin{array}{l}\text { 2013- } \\
\text { 2015. év }\end{array}$ & Összesen \\
\hline $\begin{array}{l}\text { Fertőző és parazitás } \\
\text { betegségek (A00-B99) }\end{array}$ & & & 1 & 1 \\
\hline $\begin{array}{l}\text { Endokrin, táplálkozási és } \\
\text { anyagcsere-betegségek } \\
\text { (E00-E90) }\end{array}$ & & & 1 & 1 \\
\hline $\begin{array}{l}\text { Az idegrendszer } \\
\text { betegségei (G00-G99) }\end{array}$ & 6 & 13 & 11 & 30 \\
\hline $\begin{array}{l}\text { A keringési rendszer } \\
\text { betegségei (I00-I99) }\end{array}$ & 29 & 19 & 10 & 62 \\
\hline $\begin{array}{l}\text { A légzőrendszer } \\
\text { betegségei (J00-J99) }\end{array}$ & 2 & 3 & 3 & 10 \\
\hline $\begin{array}{l}\text { Az emésztőrendszer } \\
\text { betegségei (K00-K93) }\end{array}$ & 2 & & 1 & 3 \\
\hline $\begin{array}{l}\text { Sérülés, mérgezés és } \\
\text { külső okok bizonyos } \\
\text { egyéb következményei } \\
\text { (S00-T98) }\end{array}$ & 57 & 33 & 40 & 150 \\
\hline $\begin{array}{l}\text { Transzport a } \\
\text { sürgósségi centrumba }\end{array}$ & 96 & 68 & 67 & 257 \\
\hline $\begin{array}{l}\text { Direkt transzport az } \\
\text { intervenciós egységbe } \\
\text { (PCI, thrombectomia) }\end{array}$ & & 18 & 22 & 40 \\
\hline Elszállítás & & 2 & 5 & 14 \\
\hline Mindösszesen & 96 & 88 & 94 & 311 \\
\hline
\end{tabular}

$\mathrm{Az}$ I. szint kivételével valamennyi triázsszinten a betegellátás megkezdésének átlagos ideje időlimiten ( 1 . táblázat) belülre esett.

A triázs I. szintü betegek aránya a vizsgált periódus alatt nem változott. Az időlimiten túl megkezdett ellátások aránya $5,7 \%$ volt. Itt jelenítjük meg azt a 238 beteget $(0,2 \%)$ is, akiket a reanimációs szolgálatunk - más kórházi osztályokon - látott el. A vizsgált periódus alatt a III. és a IV. triázsszint aránya nőtt, miközben a II. és az V. szint aránya és száma is csökkent (5. ábra).

Szembetűnő, hogy a III. szinten $25 \%$ fölé emelkedett a 60 percen túl megkezdett ellátás. A IV. és az V. szinteken a betegek több mint a felét az eggyel magasabb triázsszint időlimitén belül sikerült ellátnunk (6. ábra). Az V. szinten szignifikánsan $(\mathrm{p}<0,05)$ nagyobb a munkanapon, munkaidőben vizsgáltak aránya (7. ábra).

\section{BNO-fócsoportok és-alcsoportok szerinti megoszlás}

Elemzésünk során a BNO-kódokat (több mint 11000 kód definiált) az első három karakterig dolgoztuk fel. Az elsődleges diagnózis alapján betegeink 40\%-át a „Sérülés, mérgezés és külső okok bizonyos egyéb következményei” (S00-T98) csoport képezte. A BNO-föcsoportok gyakoriság szerinti első hat hely valamelyikén osztozott
4. táblázat |A 2013-2015. év között megjelent betegek BNO-föcsoportjainak aránya csökkenő sorrendben $(\mathrm{n}=106203)$

\begin{tabular}{llll}
\hline BNO-fócsoportok 2013. & $2014 . \quad 2015$. & $\begin{array}{l}2013- \\
2015 .\end{array}$
\end{tabular}

XIX. Sérülés, mérgezés és külső

$41,5 \% \quad 39,1 \% \quad 38,9 \% \quad 39,8 \%$ okok bizonyos egyéb

következményei (S00-T98)

XVIII. Máshova nem osztályozott $\quad 20,2 \% \quad 23,2 \% \quad 22,6 \% \quad 22,0 \%$ tünetek, jelek és kóros klinikai és laboratóriumi leletek (R00-R99)

IX. A keringési rendszer betegségei (I00-I99)

$\mathrm{X}$. A légzőrendszer betegségei (J00-J99)

XI. Az emésztőrendszer betegségei (K00-K93)

XXII. Speciális kódok (U00-U99)

IV. Endokrin, táplálkozási és anyagcsere-betegségek (E00E90)

XIV. Az urogenitalis rendszer megbetegedései (N00-N99)

XIII. A csont-izom rendszer és kötőszövet betegségei (M00M99)

I. Fertőző és parazitás betegségek (A00-B99)

VI. Az idegrendszer betegségei (G00-G99)

V. Mentális és viselkedészavarok (F00-F99)

VIII. A fül és a csecsnyúlvány megbetegedései (H60-H95)

XII. A bőr és bőr alatti szövet betegségei (L00-L99)

III. A vér és a vérképző szervek betegségei és az immunrendszert érintő bizonyos rendellenességek (D58-D89)

II. Daganatok (C00-D48)

VII. A szem és függelékeinek betegségei (H00-H59)

XVI. A perinatalis szakban keletkező bizonyos állapotok (P00-P96)

XVII. Veleszületett

$7,2 \% \quad 7,4 \% \quad 7,2 \% \quad 7,3 \%$

$4,2 \% \quad 4,4 \% \quad 4,9 \% \quad 4,5 \%$

$4,5 \% \quad 4,2 \% \quad 4,3 \% \quad 4,3 \%$

$4,1 \% \quad 3,6 \% \quad 3,8 \% \quad 3,8 \%$

$3,3 \% \quad 2,9 \% \quad 3,3 \% \quad 3,2 \%$

$3,2 \% \quad 3,2 \% \quad 3,2 \% \quad 3,2 \%$

$2,6 \% \quad 3,0 \% \quad 2,8 \% \quad 2,8 \%$

$2,6 \% \quad 2,2 \% \quad 2,7 \% \quad 2,5 \%$

$2,3 \% \quad 2,1 \% \quad 2,1 \% \quad 2,2 \%$

$1,6 \% \quad 1,7 \% \quad 1,8 \% \quad 1,7 \%$

$0,8 \% \quad 0,8 \% \quad 0,7 \% \quad 0,8 \%$

$0,7 \% \quad 0,8 \% \quad 0,7 \% \quad 0,7 \%$

$0,6 \% \quad 0,6 \% \quad 0,6 \% \quad 0,6 \%$

rendellenességek, deformitások és

kromoszómaabnormitások

(Q00-Q99)

XV. Terhesség, szülés és a gyermekágy (O00-O99)

Összesen $100 \% \quad 100 \% \quad 100 \% \quad 100 \%$

átlagosan öt betegből négy $(81,8 \%)$, míg a fennmaradó tizenhat BNO-fócsoporton átlagosan minden ötödik beteg $(18,2 \%)$ (4. táblázat). 


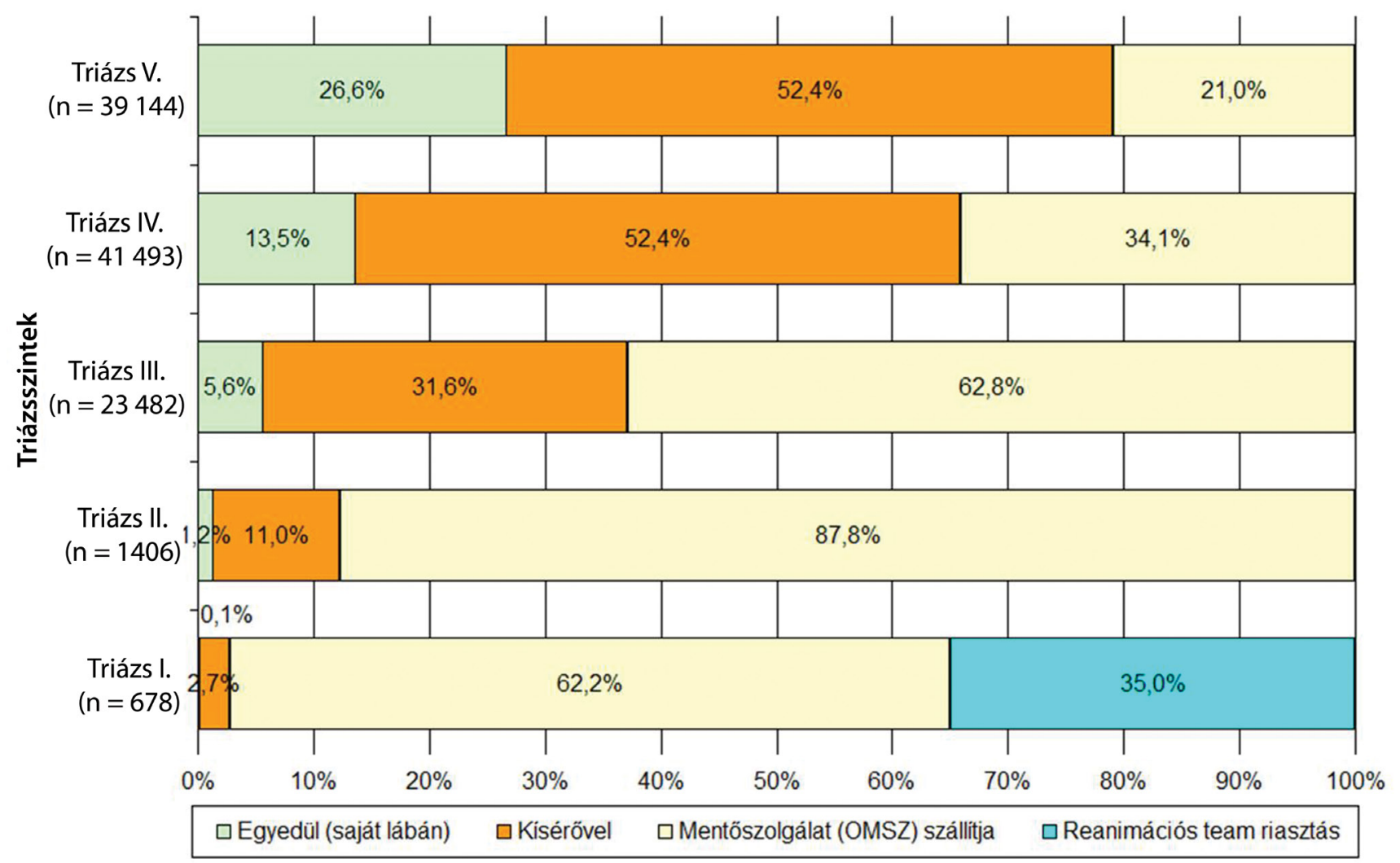

4. ábra $\quad$ Az érkezés módja szerinti megoszlás az egyes triázsszinteken $(\mathrm{n}=106203)$

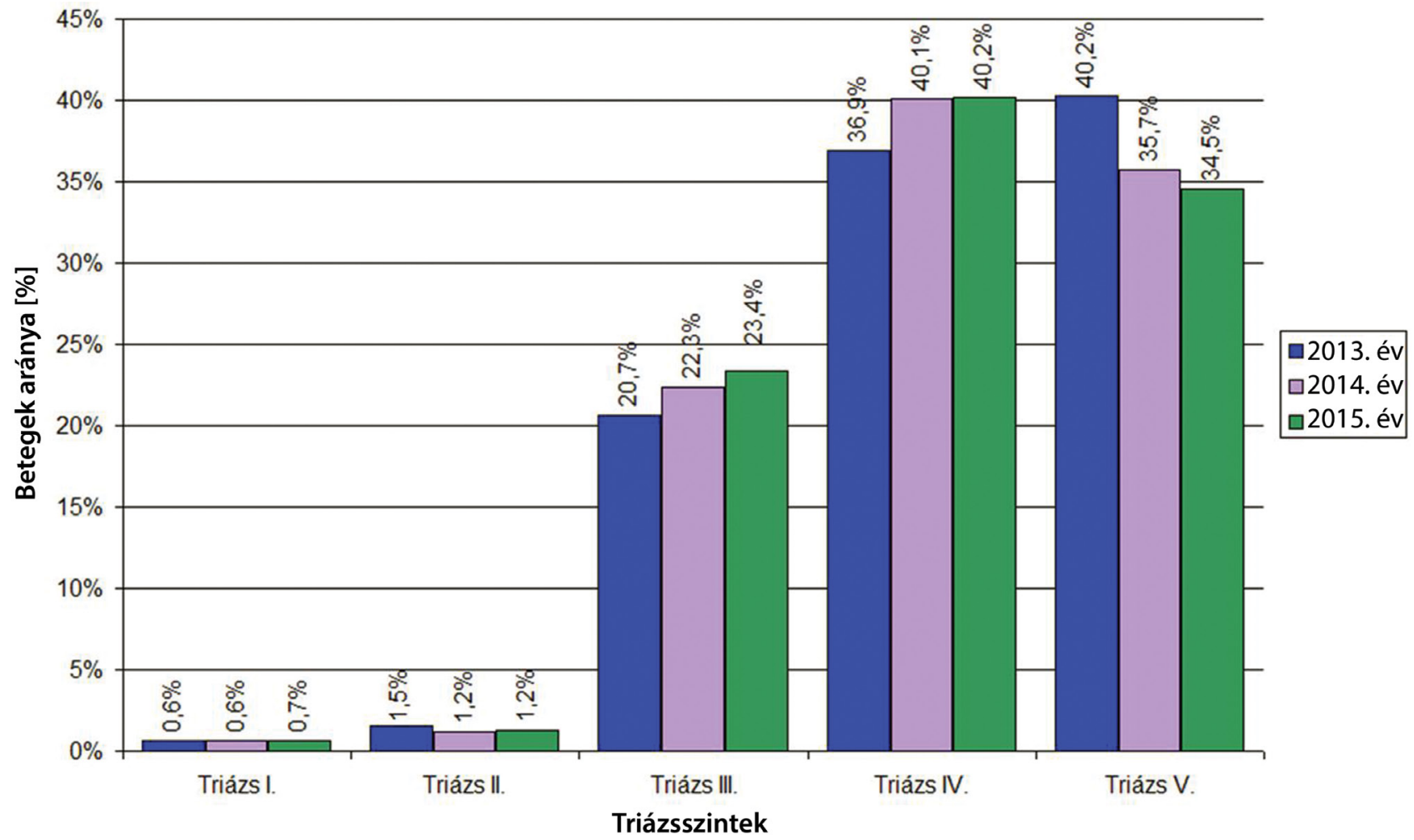

5. ábra | Az egyes triázsszinteken a betegek aránya 2013-2015-ben $(\mathrm{n}=106203)$ 


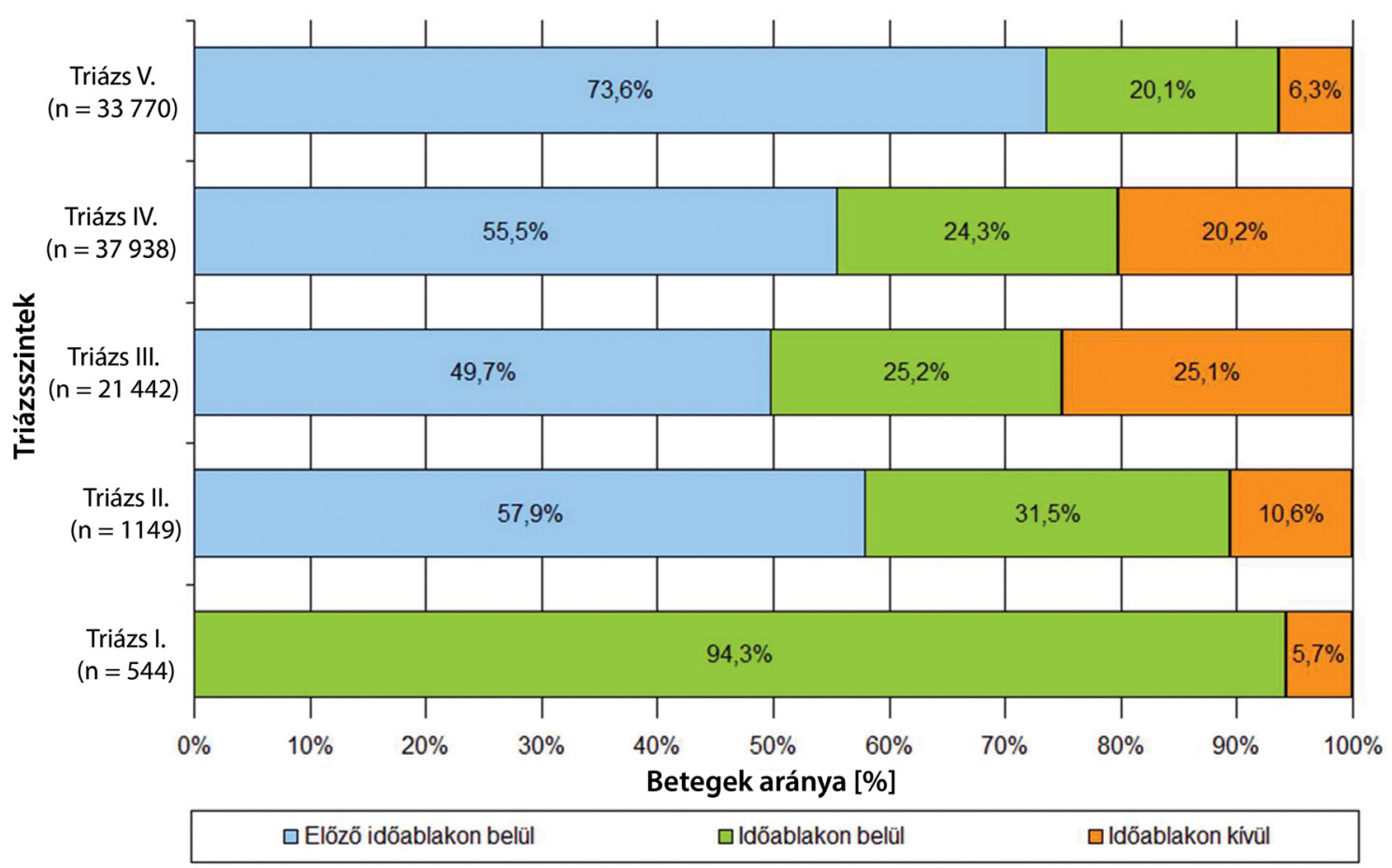

6. ábra

| Az egyes triázsszinteken a hozzá tartozó időablakon belüli ellátottak aránya $(\mathrm{n}=94843)$

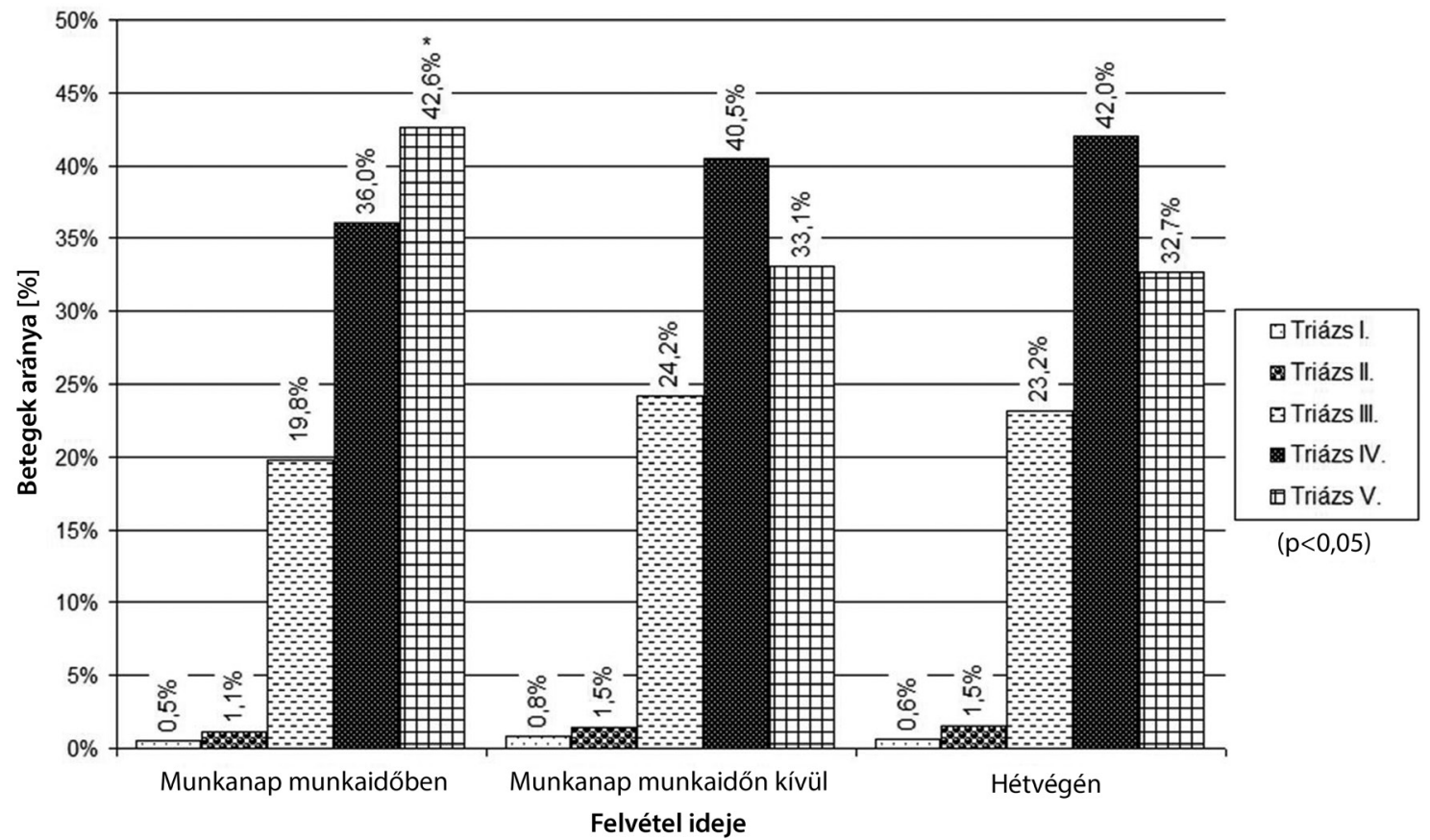

7. ábra | A különböző triázsszinteken a felvétel időpontja szerinti megoszlás 2013-2015-ben (n = 106203$)$

Húszéves kor felett a sérülés, mérgezések föcsoport (S00-T98) gyakorisága lineárisan csökkent, és csak a nyolcvan év felettiek körében mutatott emelkedést. A keringési rendszer betegségeinek (I00-I99) gyakorisága az életkorral folyamatosan növekedett (8. ábra).

A feltüntetett 1\%-ot meghaladó gyakoriságú 24 betegség- és sérülésalcsoport tette ki az összes diagnózis háromnegyed részét $(75,1 \%)$ (5. táblázat).

\section{A betegek ellátás utáni elhelyezése}

Ellátás után a betegek közel háromnegyedét $(72,9 \%)$ otthonába bocsátottuk, közülük 812 beteg $(1,0 \%)$ readmissziója történt 48 órán belül a sürgősségi centrumban.

Az önkényesen távozók $(3,0 \%)$ a centrumban töltött átlagosan 172 perc után döntöttek a távozás mellett. A férfiak $(\mathrm{n}=2190)$ türelmesebbnek bizonyultak a nők- 


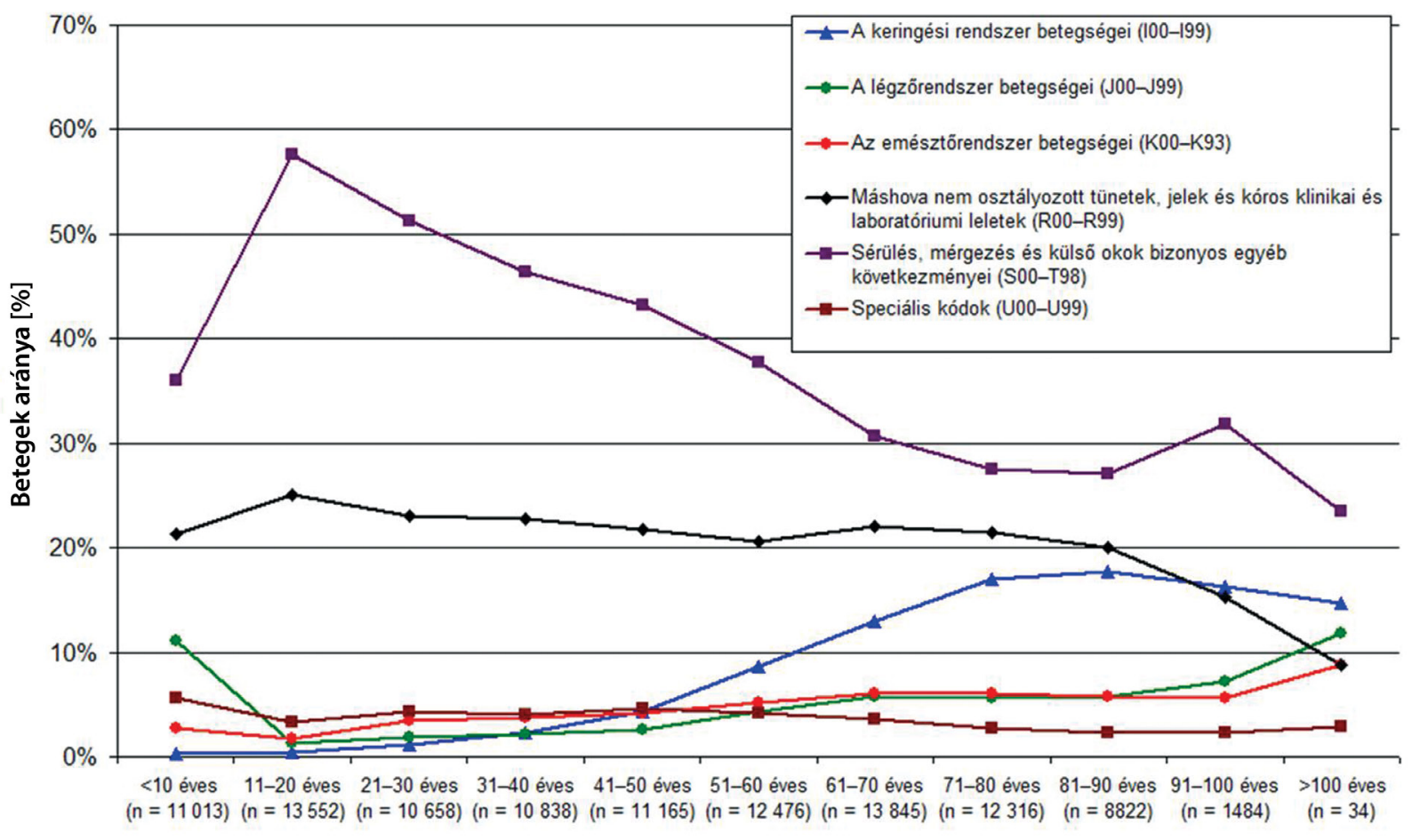

Korcsoport (elemszám)

8. ábra | A hat leggyakoribb BNO-fócsoport megoszlása korcsoportonként 2013-2015-ben $(\mathrm{n}=106203)$

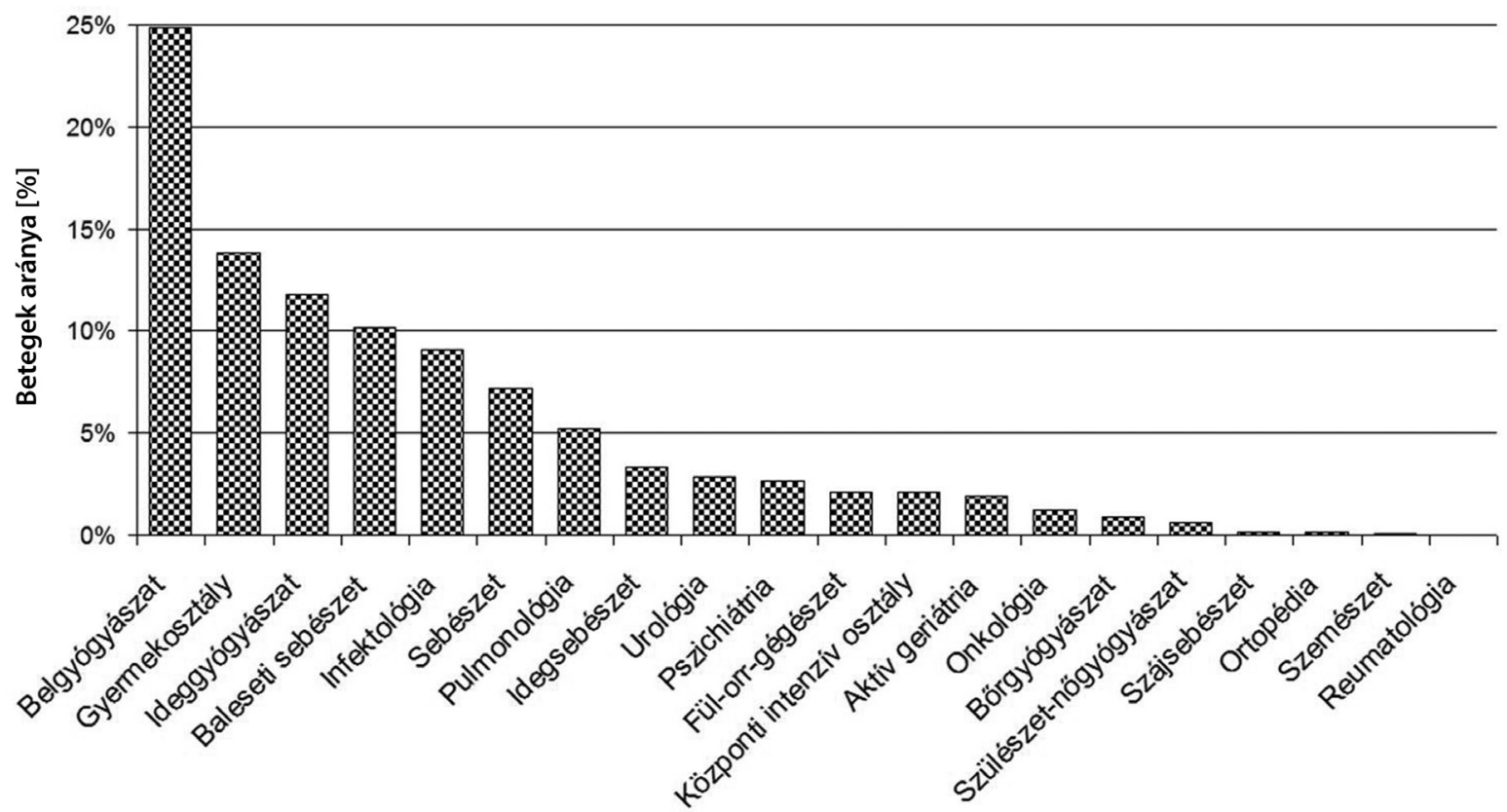

9. ábra | A hospitalizált betegek megoszlása osztályonkénti bontásban 2013-2015-ben (n = 22 679)

nél $(\mathrm{n}=962)(184$ perc vs. 144 perc). Az önkényesen távozók $(\mathrm{n}=3152)$ readmissziós aránya $5,4 \%$-a $(170$ beteg) volt 48 órán belül (2. táblázat).

A további kórházi elhelyezést és ellátást igénylők aránya $21,4 \%$ volt. A hospitalizált betegek 24,9\%-a ( $\mathrm{n}=5429)$ „belgyógyászati profilú” osztályra került felvételre. Átlagosan minden hetedik beteget a gyermek- osztályon (13,8\%), míg minden nyolcadikat a neurológián (11,8\%) helyeztünk el (9. ábra).

A belgyógyászati osztályokra áthelyezettek 41,3\%-a keringési rendszer betegségei (I00-I99), 22,2\%-a emésztőrendszer betegségei (K00-K93) és 12,6\%-a máshova nem osztályozott tünetek, jelek és kóros klinikai leletek (R00-R99) miatt került felvételre. Számottevő még az 
5. táblázat $\mid$ A leggyakoribb $(>1 \%)$ betegség- és sérüléscsoportok gyakorisága a KMOK-SBC-ban, 2013-2015 ( $\mathrm{n}=106203$ )

Betegség- és sérüléscsoportok (háromkarakteres BNO-kódok)

A csukló és a kéz sérülései (S60-S69)

Előfordulás

Általános tünetek és jelek (R50-R69) $8,8 \%$

Fejsérülések (S00-S09)

$8,7 \%$

$6,6 \%$

Az emésztőrendszert és hasat illető tünetek és jelek (R10-R19)

A boka és láb sérülései (S90-S99)

A keringési és légzési rendszert illető tünetek és jelek (R00-R09)

A térd és lábszár sérülései (S80-S89)

A könyök és alkar sérülései (S50-S59)

A szívbetegség egyéb formái (I30-I52)

Anyagcsere-rendellenességek (E70-E90)

A mellkas sérülései (S20-S29)

A váll és a felkar sérülései (S40-S49)

Elsősorban nem gyógyszerként használt anyagok toxikus hatása (T51-T65)

A csípő és comb sérülései (S70-S79)

A felismerést, percepciót, érzelmi állapotot és magatartást illetô tünetek és jelek (R40-R46)

Cerebrovascularis betegségek (I60-I69)

Sine morbo (U9990)

Epizodikus és paroxysmalis rendellenességek (G40G47)

Triázs továbbirányította (U9999)

Urolithiasis (N20-N23)

Egyéb heveny alsó légúti fertőzések (J20-J22)

A húgyrendszer egyéb betegségei (N30-N39)

Influenza és tüdőgyulladás (J10-J18)

Az epehólyag, az epeutak és hasnyálmirigy betegségei (K80-K87)

endokrin és anyagcsere-betegségek (E00-E90) nagyobb aránya $(7,2 \%)$. A négy csoport együttesen a belgyógyászatra áthelyezett betegek $83,3 \%$-át adta.

\section{A reanimációs team és elhunytak}

A három év alatt 485 beteg $(0,46 \%)$ hunyt el, ideértve az egyéb osztályokon fekvő betegek sikertelen reanimációit is. Az osztály tevékenységi körébe tartozó intézeti reanimációs szolgálat $[22,23]$ eredményessége a három év alatt $43,9 \%$ volt (2. táblázat).

\section{Megbeszélés}

Az ellátandók száma nem egzakt; szakmánként változó, nagyjából 500 ezer före tehető. Elemzésünk idején Somogy megye lakosságának 48\%-a férfi, 52\%-a nő volt,

a férfiak mégis gyakrabban vették igénybe az ellátást. Hatvanöt éves kor felett az élethossz végéig fennmaradó női dominancia feltehetốen a nők hosszabb élettartamával magyarázható. Egy ausztrál tanulmány hasonló férfidominanciáról ( $52 \%$ vs. $48 \%$ ) számolt be az aktív életkorúak között, míg egy egyesült államokbeli közlemény alapján női dominancia figyelhető meg $(54,7 \%$ vs. $45,3 \%)[5,6]$.

A centrumunkban ellátott gyermekkorúak aránya nagyobb volt, mint a megye tizennyolc év alatti lakosságának aránya $(21,0 \%$ vs. 16,4\%) [24]. Ennek hátterében a fesztiválturizmus, az alapellátásban mutatkozó orvoshiány, valamint a megyében - egymástól 80 km-re fekvő két gyermekosztály rendelkezésre állása valószínúsíthető. A nyolcvan évnél idősebbek aránya a vizsgált periódusban megközelítette a $10 \%$-ot, bár az ellátási területen a hasonló életkorúak aránya mindössze 3,6\% volt. Hasonló eredményt talált Lowthian csoportja is [6]. Felismerve a fejlett társadalmak elöregedésének problémáját, az American College of Emergency Physicians 2014-ben közzétett - az időskorúak ellátásával kapcsolatos - irányelvéhez [11] több szervezet is csatlakozott $[25,26]$. Ezen első hazai adatok megerősítik, hogy a társadalom elöregedése a geriátriai betegek megjelenésének extrém növekedését generálja a sürgósségi ellátásban [11].

A vizsgált időszakban jelentős szezonális, heti és napszaki eltéréseket találtunk. Az évszaki ingadozás hasonló a Pitts munkacsoportja által publikált adatokhoz [27]. Tanulmányunk alapján a hét első munkanapjain, valamint a munkanapon 6 és 22 óra között ellátásra jelentkezők szignifikánsan $(\mathrm{p}<0,05)$ nagyobb száma miatt a humán erőforrás szervezésénél kiemelt figyelmet kell fordítani arra, hogy - akár átkötő műszakok szervezésével - a késő esti órákig optimális létszámú munkatárs jelenlétét biztosítsuk. Hétvégi és munkaszüneti napokon pedig az esti és az éjszakai igénybevétel növekedése igényli a pluszszemélyzet szervezését.

A társadalmi esélyegyenlőség jegyében sok honfitársunk számára - a rendezetlen társadalombiztosítási jogviszonya és az alapellátás korlátozott hozzáférése miatt - egyetlen lehetőség egészségi problémáinak orvoslására a folyamatosan elérhető sürgősségi ellátórendszer. A mentőszolgálat igénybevétele meghaladta az ausztrál munkacsoport adatait $(36,4 \%$ vs. $23,1 \%)[6]$. Ez a különbség 136 millió egyesült államokbeli beteg adataihoz képest még nagyobb, ahol a mentőszolgálatot igénybe vevők aránya $15,7 \%$ volt [28]. Az eltérések adódhatnak az egészségügyi rendszerek különböző szervezéséből vagy demográfiai viszonyaiból éppúgy, mint közlekedési körülményekből. A nagy különbségek ismeretében felvetődik az igénybevétel indokoltságának kérdése. Tapasztaltuk, hogy a korlátozás nélküli igénybevételek, beutalások mögött - sajnálatos módon - nemritkán a diagnosztikai és egyéb vizsgálati várólisták megkerülésének szándéka áll. A helikopterrel érkezett, döntően kritikus állapotú traumás sérültek jelentőségét az adja, hogy bár arányuk nem nagy, a centrumokba szállításuk egyértel- 
múen szakmai előnyökkel jár [29]. Adekvát ellátásuk miatt a repülési időszak alatt folyamatosan elérhető kvalifikált és riasztható team szervezése szükséges.

Számos ötfokozatú triázsrendszer terjedt el a világon az ellátási szintekhez különböző időlimiteket használva [30]. Az osztályozás megkönnyítésére és gyorsabb elvégzése érdekében az elektronikusan támogatott változatok is sorra jelentek meg [31, 32]. Hazánkban is elengedhetetlen a medikai informatikai rendszerek ez irányú fejlesztése. Szembetûnő, hogy az I. és II. szintre sorolt betegek aránya a nemzetközi adatokkal összehasonlítva kisebb [5, 6, 33], ami alultriázsolásra utalhat, míg a III. és IV. szintre soroltak aránya nagyobb, mint például a 119 millió beteg adataiból készült elemzésben [27]. Megjegyezzük, hogy az időkorlátok eltérnek az általunk használttól: az V. szinten lévő betegek ellátására 2-24 óra közötti időintervallum áll rendelkezésre [27]. A betegtorlódások, az időlimitek túllépése és az összehasonlíthatóság miatt ausztrál szerző́k egy nemzetközi triázsskála bevezetését javasolták [34, 35]. A hétköznap munkaidőben megjelenő V. triázsszintú betegek szignifikánsan $(\mathrm{p}<0,05)$ nagyobb aránya a sürgősségi ellátás mindenki számára korlátozások nélküli, folyamatos elérhetôségét reprezentálja. Ezen adat felveti a háziorvosi rendelések helyetti igénybevétel lehetőségét, amelynek okai más jellegú elemzést igényelnek.

Pácienseink több mint 50\%-ának vizsgálatát az eggyel magasabb triázsszint időablakán belül kezdtük meg, alátámasztva az időmenedzsment kiemelt fontosságát. Eredményeink megerôsítették, hogy az ellátásra jelentkezők triázsszintje eltér az angolszász közleményekben publikált adatoktól. $\mathrm{Ng}$ és mtsai vizsgálatában a betegek aránya a CTAS III. szinten volt a legnagyobb $(44,3 \%)$, a II. szinten $24,4 \%$, a IV. szinten $22,4 \%$, míg az I. szinten $3,5 \%$ volt. Az V. szintre betegeik 5,5\%-a sorolódott $[34,36]$.

A dokumentálást végzők - leterheltségük és az időhiány miatt - törekedtek az egyszerúbben fellelhető és számukra ismert kódok használatára, ennek ellenére a fö- és alcsoportok elemzése így is pontosan reprezentálja a betegforgalmi trendeket. A részletes alábontó kódok elemzésére jelen dolgozat keretében nem térünk ki.

A betegek közel háromnegyede az ambuláns ellátás után otthonába bocsátható volt, amely hasonlóságot mutat ausztrál, európai és amerikai munkacsoportok eredményeivel is $[6,37,38]$. Readmissziós arányaink (1-5\%) jobbak, mint az irodalomban olvasható eredmények (16-17\%), azonban meg kell jegyeznünk, hogy e tanulmányban a readmisszió idejét 30 napban határozták meg [39]. Adataink alátámasztják, hogy a jól szervezett sürgősségi ellátás nagymértékben csökkentheti az indokolatlan kórházi felvételek arányát.

Az ellátás során elhunytak csekély száma megerősíti, hogy a sürgősségi osztály a betegek állapotstabilizálása tekintetében eredményes. A kórházon belüli reanimációs team múködtetése nagy gyakorlattal bíró, folyamatosan rendelkezésre álló csapatot igényel. Eredményeink sike- resség tekintetében - feltehetően ennek köszönhetően felülmúlják a német munkacsoport eredményeit $(43,9 \%$ vs. 33\%) [23].

\section{Következtetések}

Európában jól definiáltak a sürgősségi ellátás alapelvei, amelyek adaptációja kell, hogy alapját képezze a magyar sürgőségi ellátórendszer fejlesztésének is.

„A sürgösségi orvostan a medicina egyik ága, amely speciális tudásával és eszköztárával minden korcsoportban a megelózéstôl a diagnózis felállitásán keresztül az erösen idöfüggö, hirtelen kialakuló vagy röpid idön belül tartós károsodást okozó testi betegségek, akut viselkedészavarok gyógyitásával foglalkozik, függetlenül a páciensek egyéb alapbetegségeitöl. Ez egy olyan szakteriület, ahol az idó kritikus szerepet játszik. Az ellátás nemcsak a kórházon kivïli és belüli triázsból és az újraélesztésböl áll, hanem magában foglalja a betegek kezdeti stabilizálását, primer ellátását is állapotuktól függöen, a hazaengedésükig vagy a végleges kórbázi elhelyezésiukig. A sürgösségi szemlélet kiterjed a prehospitális és a hospitális rendszerek folyamatos fejlesztésére is" [40].

Magyarországon az egészségügy és ezen belül a sürgôsségi ellátás - mint az orvos-beteg első találkozási pontja - rejtett szociális ellátórendszeri, gondozási, ellátási és társadalmi funkciók egész sorát látja el folyamatosan (például mentálhigiénés, szociális eredetú panaszok is [13]).

A sürgősségi ellátás így nem redukálható kizárólag megelőző (szekunder és tercier prevenció [41, 42]), valamint gyógyító feladatokra. Az osztályok múködtetése a korábbi „poroszos” szemléletú egészségügyben nagy kihívást jelent. Integratív tevékenységük folytán kiszürhetők a kórházi elhelyezést nem igénylő betegek, akiknek $99 \%$-a 24 órán belül emittálható. A betegbiztonság garanciája mellett az osztályok terhelése csökken, a kórházi ágyak száma csökkenthető. A triázsszintek nemzetközi összehasonlításban eltérő karakterisztikája, a IV. és V. triázsszintúek nagy aránya alátámasztja, hogy tanulmányunkban az ellátásra jelentkezők nem kizárólag sürgősségi indikáció miatt érkeztek. Az egységes elvek mentén történő osztályozás következetes használata szükséges.

Azt hihetnénk, hogy a sürgôsségi ellátás nem más, mint az idézett definíciónak megfelelő, előre nem látható, ellátás hiányában halált vagy maradandó egészségkárosodást okozó betegségek és sérülések felismerését, gyógyítását, valamint a további szövődmények megelőzését szolgáló önálló diszciplína, azonban a hazai valóság ennél bonyolultabb.

Anyagi támogatás: A közlemény megírása, illetve az alapját képező és kapcsolódó kutatómunka anyagi támogatásban nem részesült. 
Szerzôi munkamegosztás: V. Cs.: A közlemény alapötlete, az elemzés megtervezése, az irodalmi háttér feldolgozása, értékelés, a kézirat elkészítése. L. Zs.: Statisztikai elemzés, értékelés, a kézirat tartalmi és stilisztikai javítása. S. V.: A dokumentáció digitalizálása, adatfeldolgozás. O. T.: A kézirat szövegezésének kritikai olvasata, korrekciós javaslatok, a kézirat elkészítésének szakmai ellenőrzése. Az ábrák kivétel nélkül a kutatás keretében készültek, saját ábrák. Valamennyi szerző egyaránt és egyforma mértékben járult hozzá az ábrák elkészítéséhez. A közlemény végleges változatát valamennyi szerző elolvasta és jóváhagyta.

Érdekeltségek: A szerzőknek nincsenek érdekeltségeik.

\section{Irodalom}

[1] Decree No. 47/2004 (V. 11.) of the Ministry of Health, Social and Family Affairs on certain organisational questions of the continuous operation of healthcare services. [Az egészségügyi, szociális és családügyi miniszter 47/2004. (V. 11.) ESzCsM rendelete az egészségügyi ellátás folyamatos múködtetésének egyes szervezési kérdéseiről.] Magyar Közlöny. 2004; 64: 6635-6642. Available from: http://njt.hu/cgi_bin/njt_doc.cgi?docid= 84476.327322 (2017-01-30) [Hungarian]

[2] Decree No. 60/2003. (X. 20.) of the Ministry of Health, Social and Family Affairs on the minimum standards of providing health care services. [Az egészségügyi, szociális és családügyi miniszter 60/2003. (X. 20.) ESzCsM rendelete az egészségügyi szolgáltatások nyújtásához szükséges szakmai minimumfeltételekről.] Magyar Közlöny. 2003; 120: 8692-8942. Available from: http://njt.hu/cgi_bin/njt_doc.cgi?docid=75259. 320115 (2017-01-30) [Hungarian]

[3] Decree No. 52/2006 (XII. 28.) of the Ministry of Health on emergency health care services specifies the list of situations which qualify as "emergency". [Az egészségügyi miniszter 52/2006. (XII. 28.) EüM rendelete a sürgős szükség körébe tartozó egyes egészségügyi szolgáltatásokról.] Magyar Közlöny. 2006; 165: 14137-14138. Available from: http://njt.hu/cgi_ bin/njt_doc.cgi?docid=103128.144918 (2017-01-30) [Hungarian]

[4] Reeder TJ, Benson NH. Performance monitoring and development. In: Aghababian RV. (ed.) Principles of emergency medicine. [Teljesítmény-ellenőrzés és -fejlesztés. In: Aghababian RV. (szerk.) A sürgősségi orvoslás alapjai.] Medicina Könyvkiadó, Budapest, 2011; pp. 1037-1040. [Hungarian]

[5] Tang N, Stein J, Hsia RY, et al. Trends and characteristics of US emergency department visits, 1997-2007. JAMA. 2010; 304: 664-670.

[6] Lowthian JA, Curtis AJ, Jolley DJ, et al. Demand at the emergency department front door: 10-year trends in presentations. Med J Aust. 2012; 196: 128-132.

[7] Aboagye-Sarfo P, Mai Q, Sanfilippo FM, et al. Growth in Western Australian emergency department demand during 20072013 is due to people with urgent and complex care needs. Emerg Med Australas. 2015; 27: 202-209.

[8] Shah MN, Bazarian JJ, Lerner EB, et al. The epidemiology of emergency medical services use by older adults: an analysis of the National Hospital Ambulatory Medical Care Survey. Acad Emerg Med. 2007; 14: 441-447.

[9] Zakariassen E, Hansen EH, Hunskaar S. Incidence of emergency contacts (red responses) to Norwegian emergency primary health care services in 2007 - a prospective observational study. BMC Scand J Trauma Resusc Emerg Med. 2009; 17: 30.
[10] Zakariassen E, Burman RA, Hunskaar S. The epidemiology of medical emergency contacts outside hospitals in Norway - a prospective population based study. Scand J Trauma Resusc Emerg Med. 2010; 18: 9.

[11] American College of Emergency Physicians, American Geriatrics Society, Emergency Nurses Association, Society for Academic Emergency Medicine, Geriatric Emergency Department Guidelines Task Force. Geriatric emergency department guidelines. Ann Emerg Med. 2014; 63: e7-e25.

[12] Dwyer R, Stoelwinder J, Gabbe B, et al. Unplanned transfer to emergency departments for frail elderly residents of aged care facilities: A review of patient and organizational factors. J Am Med Dir Assoc. 2015; 16: 551-562.

[13] Hungarian Emergency Triage System Textbook. [Magyar Sürgősségi Triage Rendszer tankönyv. Triázs oktatási források CAEP-NWG.] MSOTKE, Budapest, 2016. [Hungarian]

[14] BNO-10. The International Statistical Classification of Diseases and Related Health Problems (Tenth Revision). Népjóléti Minisztérium, Budapest, 1995.

[15] Bullard MJ, Unger B, Spence J, et al. Revisions to the Canadian Emergency Department Triage and Acuity Scale (CTAS) adult guidelines. CJEM. 2008; 10: 136-151.

[16] Teasdale G, Jennett B. Assessment of coma and impaired consciousness. A practical scale. Lancet. 1974; 2: 81-84.

[17] Baker SP, O'Neill B, Haddon W Jr, et al. The injury severity score: a method for describing patients with multiple injuries and evaluating emergency care. J Trauma. 1974; 14: 187-196.

[18] Champion HR, Sacco WJ, Carnazzo AJ, et al. Trauma score. Crit Care Med. 1981; 9: 672-676.

[19] NIH Stroke Scale (NIHSS). Available from: https://www.ninds. nih.gov/search/node?keys=NIHSS\& $x=8 \& y=13$ (2017-02-01)

[20] Thim T, Krarup NH, Grove EL, et al. Initial assessment and treatment with the Airway, Breathing, Circulation, Disability, Exposure (ABCDE) approach. Int J Gen Med. 2012; 5: 117121.

[21] Dinya E. Biometrics in medical practice. [Biometria az orvosi gyakorlatban.] Medicina Könyvkiadó, Budapest, 2001. [Hungarian]

[22] Neukamm J, Gräsner JT, Schewe JC, et al. The impact of response time reliability on CPR incidence and resuscitation success: a benchmark study from the German Resuscitation Registry. Crit Care. 2011; 15: R282.

[23] Kordelas L, Jánosi RA, Böse D, et al. Successful implementation of an "in-hospital resuscitation team" in a university hospital. [Erfolgreicher Einsatz eines „In-Hospital-Reanimationsteams“ in einem Universitätsklinikum.] Dtsch Med Wochenschr. 2011; 136: 1359-1364. [German]

[24] The population in Somogy County on January 1, 2015. [Somogy megye állandó lakossága 2015. január 1-jén.] KSH, Budapest, 2016. Available from: https://www.ksh.hu/docs/hun/ hnk/hnk_2015.xls (2017-02-01) [Hungarian]

[25] Carpenter CR, Bromley M, Caterino JM, et al. Optimal older adult emergency care: introducing multidisciplinary geriatric emergency department guidelines from the American College of Emergency Physicians, American Geriatrics Society, Emergency Nurses Association, and Society for Academic Emergency Medicine. Acad Emerg Med. 2014; 21: 806-809.

[26] Carpenter CR, Bromley M, Caterino JM, et al. Optimal older adult emergency care: introducing multidisciplinary geriatric emergency department guidelines from the American College of Emergency Physicians, American Geriatrics Society, Emergency Nurses Association, and Society for Academic Emergency Medicine. J Am Geriatr Soc. 2014; 62: 1360-1363.

[27] Pitts SR, Niska RW, Xu J, et al. National Hospital Ambulatory Medical Care Survey: 2006 emergency department summary. Natl Health Stat Report. 2008; 7: 1-38.

[28] National Hospital Ambulatory Medical Care Survey: 2011 Emergency Department summary tables. National Center for 
Health Statistics. Available from: https://www.cdc.gov/nchs/ data/ahcd/nhamcs_emergency/2011_ed_web_tables.pdf (2017-01-04)

[29] Newgard CD, McConnell KJ, Hedges JR, et al. The benefit of higher level of care transfer of injured patients from nontertiary hospital emergency departments. J Trauma. 2007; 63: 965-971.

[30] Tóth Z. The importance and methods of triage in emergency medicine. [A betegosztályozás (triage) jelentősége és módszerei a sürgősségi betegellátásban.] Újraélesztés (Resustitatio Hungarica). 2007; 5: 9-19. [Hungarian]

[31] Dong SL, Bullard MJ, Meurer DP, et al. Predictive validity of a computerized emergency triage tool. Acad Emerg Med. 2007; 14: 16-21.

[32] Amthauer C, Cunha ML. Manchester Triage System: main flowcharts, discriminators and outcomes of a pediatric emergency care. Rev Lat Am Enfermagem. 2016; 24: e2779.

[33] Provincial Summary: Canadian Triage and Acuity Scale (CTAS) - February 2017. Available from: http://www.ontariowaittimes. $\mathrm{com} / \mathrm{er} /$ En/ProvincialSummaryCTAS.aspx?view=1 $\quad(2017-01-$ $05)$

[34] Jelinek GA. Towards an international triage scale. Eur J Emerg Med. 2001; 8: 1-2.

[35] FitzGerald G, Jelinek GA, Scott D, et al. Emergency department triage revisited. Emerg Med J. 2010; 27: 86-92.

[36] Ng CJ, Hsu KH, Kuan JT, et al. Comparison between Canadian Triage and Acuity Scale and Taiwan Triage System in emergency departments. J Formos Med Assoc. 2010; 109: 828-837.
[37] O'Cathain A, Knowles E, Turner J, et al. Explaining variation in emergency admissions: a mixed-methods study of emergency and urgent care systems. Health Services and Delivery Research. 2014; 2: 1-158.

[38] Venkatesh AK, Dai Y, Ross JS, et al. Variation in US hospital emergency department admission rates by clinical condition. Med Care. 2015; 53: 237-244.

[39] Magdelijns FJ, Schepers L, Pijpers E, et al. Unplanned readmissions in younger and older adult patients: the role of healthcarerelated adverse events. Eur J Med Res. 2016; 21: 35.

[40] The principles of European emergency medicine. [Az európai sürgôsségi orvostan alapelvei.] Available from: http://msotke. hu/eusem_alapelvei (2017-01-04) [Hungarian]

[41] MacDonald GS, Steiner SR. Emergency medical service providers' role in the early heart attack care program: prevention and stratification strategies. Md Med J. 1997; Suppl: 67-79.

[42] Van Landschoot R, Portzky G, van Heeringen K. Knowledge, self-confidence and attitudes towards suicidal patients at Emergency and Psychiatric Departments: A randomised controlled trial of the effects of an educational poster campaign. Int J Environ Res Public Health. 2017; 14: pii: E304.

(Varga Csaba dr.,

Kaposvár, Tallián Gyula u. 20-32., 7400 e-mail: vcspaper@gmail.com)

\section{NOTA \\ Új fejlesztés az egészségügyben dolgozók, tanulók részére!}

\section{A magyar nyelvứ szakirodalmi keresőszolgáltatás}

\section{Mi a NOTA? \\ Napivizit Orvosi Tudástár Alkalmazás}

Mit tud a NOTA portál?

Megkönnyíti a magyar nyelvű szakirodalmi források keresését.

Eszköztöl függetlenül, akár okostelefonról, a betegágy mellett állva is használható.

\section{Miben kereshet a NOTA-val?}

Az Akadémiai Kiadó folyóirataiban: Orvosi Hetilap, Magyar Sebészet, Mentálhigiéné és Pszichoszomatika.

Más kiadók magyar nyelvü szakfolyóirataiban: pl. Lege Artis Medicinae, Hypertonia és Nephrologia, Ideggyógyászati Szemle.

A hatályos szakmai irányelvekben.

Magyar nyelvủ kérdésekre adott angol nyelvű találatokban, a PubMeden.

\section{nota.hu}

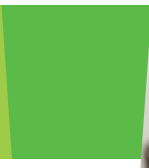

Akadémiai Kiadó

A Wolters Kluwer Csoport tagja

1117 Budapest, Prielle Kornélia u. 21-35. / Telefon: (1) 464-8246

www.akademiai.hu / www.akademiai.com

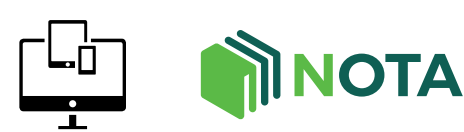

AKADÉMIAI KIADÓ 